\title{
ENERGY AND EXERGY ANALYSIS OF MOUNT SALAK GEOTHERMAL POWER PLANT UNIT 1-2-3
}

\author{
Bakhrul Ulum ${ }^{1,2^{*}}$ Nurrohman $^{2}$, Ervan Ambarita ${ }^{1}$, Yogi Sirodz Gaos ${ }^{2}$ \\ ${ }^{1}$ PT. Indonesia Power, Gunung Salak Geothermal Power Plant, Sukabumi 43357, Indonesia \\ ${ }^{2}$ Mechanical Engineering Department, Faculty of Engineering, Universitas Ibn Khaldun, Bogor \\ 16162, Indonesia
}

(Received: October 2016 / Revised: May 2017 / Accepted: October 2017)

\begin{abstract}
Excellence in skilled operation is vital for the efficiency of geothermal power plants. Mount Salak geothermal power plant unit 1-2-3 has consistently produced no less than $180 \mathrm{MWe}$ to the Java-Bali grid since its first commercial operation in 1994, with an equivalent availability factor (EAF) average of $96 \%$. Owing to this long operation period, power plant efficiency must be improved for the sustainable production of electricity. In this study, energy and exergy analysis has been undertaken to ascertain the amount of energy that is used in the power plant's current condition, and to determine the plant's overall system losses. Research was carried out by collecting data relating to temperature, pressure, and mass flow rate. Data were analyzed using the control volume to assess the thermal and mass balance and ascertain the value of exergy. Analysis was conducted theoretically and compared with results calculated by Engineering Equation Solver (EES) software. The results showed that from 1069,90 MWe in steam energy entering the system, the total amount of exergy was 302.42 MWe. Mount Salak geothermal power plant unit 1-2-3 had an overall first law efficiency of $16.75 \%$ and an overall second law efficiency of $59.27 \%$. The greatest losses - $27.84 \%$ of the total exergy - were in the condensers. This was caused by the quality of cooling water entering condensers, which was in turn a result of cooling tower performance. Results suggest that turbine unit 1 should be investigated further to determine causes of decreased capacity.
\end{abstract}

Keywords: Efficiency; Energy; Exergy; Geothermal power plant; Losses

\section{INTRODUCTION}

The Java-Bali grid system has a demand of around 24,000 MWe. Geothermal power plants contribute around $4 \%$ of overall power in the Java-Bali grid system. For base load energy, geothermal power plants have an important role in the grid system. Mount Salak geothermal power plant unit 1-2-3 continually produces $4.32 \mathrm{GWh}$ in a day, with a reliable average record of $96 \%$ equivalent availability factor (EAF).

Unit 1-2 have been in operation since 1994. Unit 3 started to operate three years after the commissioning of Unit 1-2 in 1997, with a maximum capacity of 55 MWe for each unit. In 2004, owing to the high demand of the Java-Bali interconnection grid, the power plants increased power generation capacity via some minor modifications to overall systems, resulting in a maximum capacity increase to $60 \mathrm{MWe}$ per unit.

Over the course of these long periods of operation, there have been no major equipment

*Corresponding author's email: bakhrululum19@gmail.com, Tel: +62-251-8381993, Fax: +62-251-8381993

Permalink/DOI: https://doi.org/10.14716/ijtech.v8i7.740 
replacements. This means that the degradation of equipment is likely. Indeed, the turbine, generator, condenser and cooling tower all degrade over time, undermining the production of electricity at the maximum capacity. Energy demands also increase daily. An understanding of the mechanisms that degrade energy quality, as well as a clear, systematic approach for conducting improvements, is therefore paramount (Gong \& Wall, 1997).

Energy is conserved during any process while it is transformed from one form to another. Exergy is defined as the maximum work output that could theoretically be obtained from a substance at specified thermodynamic conditions relative to its surrounding (DiPippo, 2007). For example, steam heat can be used to power a turbine, which rotates a generator that can produces electricity. The energy balance method can identify and quantify the amount of energy in a system, while the exergy balance method can identify both the quantity and quality of energy in a system (Rosen, 2002).

Many authors have been discussed the analysis on power plants that it is a powerful tool to identify and quantify energy degrading processes, since it enables the type, locations, and quantities of energy losses to be evaluated through employing the $1^{\text {st }}$ and $2^{\text {nd }}$ Laws of Thermodynamics. It also applies to geothermal power plants and fields (Cengel \& Boles, 2006; Moran \& Shapiro, 2006; Aljundi, 2009; Dincer \& Rosen, 2013).

Quijano (2000) presents exergy analysis of two geothermal fields to investigate the possibility of increasing the utilization factor by improving the thermodynamic conditions in low enthalpy wells using higher wellhead pressure operation. Self et al. (2015) conduct analysis of geothermal power plant with and without Re-Injection in Cerro Prieto 1, Mexico. Jalilinasrabady et al. (2012) developed a method to find which the best flash cycle that can be applied in Sabalan geothermal power plant that was currently under development by employing energy and exergy concept. Dagdas (2007) conducted performance analysis and optimization of a hypothetical double-flash geothermal power plant that is constructed in the condition of western Turkey based on first and second law of thermodynamics. Ameri et al. (2011) conducted energy and exergy analysis to optimize of a double flash power plant for Meskhin Shar region, Iran. A similar study performed by Pambudi et al. (2013), with case studies of a single-flash system that previously has been adopted for power generation in the Dieng geothermal power plant. Modification of the plant to double-flash system was examined and evaluated by energy and exergy analysis using actual and designed data to achieve bigger of net power output. As a convincing tool that can be applied to make improvement on geothermal power plant, energy and exergy analysis have proven the accuracy of the result, it can impact on increasing of overall power plant efficiency without major replacement of equipment (Adiprana et al., 2015). Examining another type of geothermal power plant also can rely on this analysis, Khorami et al. (2013) developed thermodynamic model and exergy analysis of a two-phase closed thermosyphon system in Organic Rankine Cycle.

This research aims to evaluate the overall operation of the power plant, with a view to maintaining sustainable power generation with higher efficiency. Field data related to temperature, pressure, and mass flow rate were used to do this study's analysis. Data were analyzed using the control volume to assess the thermal and mass balance and to subsequently ascertain the value of exergy. Analysis was conducted theoretically and compared with calculations generated by EES (Engineering Equation Solver) software.

\section{PROCESS FLOW DIAGRAM}

PT. Indonesia Power (IP), a power producer that operates 3 geothermal power plants, uses PT. Star Energy Geothermal Salak (SEGS) as its steam supplier. Steam from production wells contains approximately $75 \%$ water and $25 \%$ dry steam. Before it is supplied to the power plant, 
steam and water are divided through a separator system. The steam is then transferred to power plant units through pipes, and the water is directly pumped into the re-injection well. PT. SEGS also operate other steam treatments to separate dirt in steam. This is done via scrubbers, from which the output steam is much cleaner. Following this, the stop block valve functions as the main gate for steam to be transferred to the power plant area.

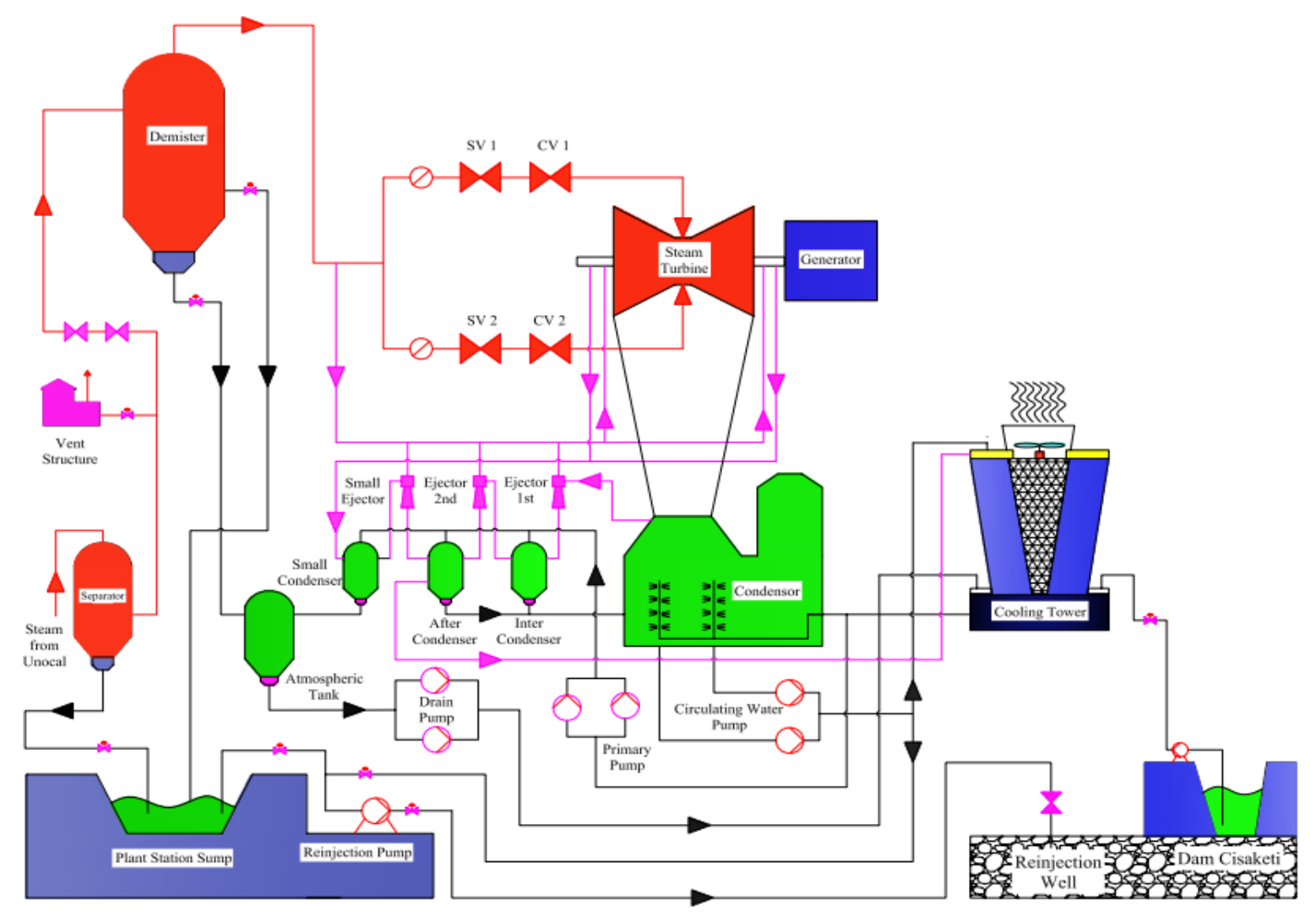

Figure 1 Process flow diagram of Mount Salak geothermal power plant unit 1-2-3

Figure 1 comprises a process flow diagram of Mount Salak Geothermal Power Plant Unit 1-2-3. All of the equipment detailed is owned and operated by PT. IP. The plant area shown in Figure 1 is the same area that research for this study was conducted.

The main unit isolation valve (MUIV) comprises the main gate for steam to enter the power plant area. After entering the power plant area, steam flows to the demister. Here, solid particles that may still be present in the steam are isolated. The moisture content of the steam can also be controlled through turbulence and impact forces between high velocity steam and the demister element. To maintain this operation, PT. IP specifies a pressure differential parameter so that pressure loss can be monitored. Multiple steam treatments are necessary to ensure the steam is in a dry condition before continuing on its power generation journey.

The output steam from the demister is divided into the main steam system and an auxiliary system. The main steam system is further divided into two flows, on the right and left side. On each side there is strainer that provides a final steam filter. Steam then flows through the stop valve (SV) and control valve (CV). The SV acts as a safety valve should any malfunctions arise, or in the case of full plant shutdown. In normal conditions, the SV is either fully open or fully closed. Meanwhile, the CV controls the steam flow rate in order to maintain the turbine speed. The turbine rotates at the impact of steam flow as it hits the chest part of turbine, 
subsequently spinning the motor blades. This rotation is set to $3000 \mathrm{rpm}$. The turbine is coupled with the generator, which therefore also rotates. The output of the generator terminal is an electrical voltage of $11.8 \mathrm{kV}$. This could be increased to $150 \mathrm{kV}$ with a step-up transformator, for synchronization to the $50 \mathrm{~Hz}$ Java-Bali Interconnection grid frequency. However, Mount Salak Unit 1-2-3 as limited scope in this regard, as the responsibility for the transmission of electric power rests with PT. PLN P2B as distributor.

Exhaust steam from the turbine flows into condenser. This is then condensed by cooling water from the cooling tower. Exhaust steam changes form from gas into water - this is known as condensate water. The condensate water is then pumped into the upper side of the cooling tower by two pumps. The main circulating pump (MCWP) sends the condensate into the cooling system by a draft fan system. This means that hot water is dropped to a lower basin via nozzles, whereby water hits air that is moved by a fan. The cold water in the lower basin is then used to cool the exhaust steam in the condenser.

For maximizing a critical vacuum condition, non-condensable gas (NCG) contained in the exhaust steam is removed by the gas removing system (GRS) in inter-after condensers, by using cooling water from the primary cooling water pump (PCWP). The condensate water flows through the condenser, and NCG is released into the atmosphere through the fan stack of the fan cooling tower (FCT).

If the unit shuts down, cooling water in the lower basin cooling tower is filled using the river pump, which is extracted from the Dam Cisaketi River. Some condensate water pumped by the MCWP is delivered to the re-injection well by the re-injection pump that is owned and operated by PT. SEGS. PT. IP needs to coordinate to balance the level in the basin cooling tower.

These overall processes have been analyzed theoretically using thermodynamics, and with EES as a comparative reference.

\subsection{Demister}

The demister comprises one kind of steam treatment. It consists of two outlets. The main steam goes directly to rotate the turbine, and the auxiliary steam is used by the GRS to motivate steam for ejectors. Table 1 shows the specification of Demister Unit 1-2-3.

Table 1 Demister unit 1-2-3

\begin{tabular}{|c|c|c|}
\hline Parameter & Unit 1-2 & Unit 3 \\
\hline Manufacturer & \multicolumn{2}{|c|}{ Forain Milano Italy } \\
\hline Operating inlet pressure & \multicolumn{2}{|c|}{7.1 bar abs } \\
\hline Operating temperature & \multicolumn{2}{|c|}{$165.5^{\circ} \mathrm{C}$} \\
\hline Inlet steam flow & \multicolumn{2}{|c|}{$436910 \mathrm{~kg} / \mathrm{h}$} \\
\hline
\end{tabular}

Some assumptions were made to do the following calculation and analysis thermodynamically:

1. The process is thermodynamically adiabatic.

2. The pressure and flow rate of steam from production wells are steady and constant.

3. Solid particles and moisture content which are caught flow through valves into the drain system. In the field, there is no flow meter to measure this.

4. In conditions of normal operation, it is assumed that the amounts of steam in the inlet and outlet demister are the same amount, and that there is no leakage in the demister.

The energy balance of inlet and outlet steam in demister can be stated as:

$$
\begin{aligned}
& \Sigma E 1=\Sigma E 2+\Sigma E 3+\Sigma E_{\text {drain }} \\
& \dot{m}_{1} h_{1}=\dot{m}_{2} h_{2}+\dot{m}_{3} h_{3}+\Sigma E_{\text {drain }}
\end{aligned}
$$


where the total amount of energy entering demister $\Sigma E 1(\mathrm{~kW})$ is equal to the total amount of energy of main steam $\Sigma E 2(\mathrm{~kW})$, auxiliary steam $\Sigma E 3(\mathrm{~kW})$, and wasted steam in drain system $\Sigma E_{\text {drain }}(\mathrm{kW}) . \dot{m}(\mathrm{~kg} / \mathrm{s})$ stands for flow rate data, and $h(\mathrm{~kJ} / \mathrm{kg})$ stands for enthalpy in each steam condition, the exergy analysis can be expressed as:

$$
\begin{gathered}
\Sigma X 1=\Sigma X 2+\Sigma X 3+I_{\text {Demister }} \\
\dot{m}_{1} e_{1}=\dot{m}_{2} e_{2}+\dot{m}_{3} e_{3}+I_{\text {Demister }}
\end{gathered}
$$

where total amount of demister inlet exergy $\Sigma X 1(\mathrm{~kW})$ is summed up as exergy of main steam $\Sigma X 2(\mathrm{~kW})$, auxiliary steam $\Sigma X 3(\mathrm{~kW})$, and irreversibility of demister $I_{\text {Demister }}(\mathrm{kW}) . e(\mathrm{~kJ} / \mathrm{kg})$ stands for specific exergy in each condition.

\subsection{Turbine}

The turbine in the geothermal power plant has been customized for steam use. The turbine is designed to change the energy form of steam into mechanical energi via turbine rotation. The generator is coupled in parallel with the turbine. As both rotor shafts are joined, the rotation of turbine and generator will always be at the same speed.

After the turbine and generator reach $3000 \mathrm{rpm}$ and the generator is ready to synchronize with the interconnection grid and generate electrical energy, the generator receives DC current by excitation that is then transferred to the rotor winding and thus the magnetic poles of the generator. The rotor inducts stator winding so that it generates electromotive force. Table 2 shows specification of turbine unit 1-2-3.

Table 2 Turbine unit 1-2-3

\begin{tabular}{lcc}
\hline \multicolumn{1}{c}{ Parameter } & Unit 1-2 & Unit 3 \\
\hline Manufacturer & Ansaldo Compenti \\
Steam inlet press. & $6.63 \mathrm{bar}$ abs \\
Exhaust steam Press & $0.102 \mathrm{bar}$ abs \\
Steam temperature & $162^{\circ} \mathrm{C}$ \\
Blade stages & $6+6$ \\
\hline
\end{tabular}

Assumptions are required to do calculation and analysis:

1. The process is thermodynamically adiabatic.

2. The generator efficiency is, from the latest calculation, in the following order for Unit 1-23: $97.99 \%$; $97.99 \% ; 98.02 \%$.

The equation of energy balance in the turbine is described as:

$$
\begin{gathered}
\Sigma E 2=\Sigma E 4+W t \\
\dot{m}_{2} h_{2}=\dot{m}_{4} h_{4}+W t
\end{gathered}
$$

The total amount of energy from expanded steam $\Sigma E 2(\mathrm{~kW})$ is equivalent to the amount of energy of exhaust steam $\Sigma E 4(\mathrm{~kW})$ and the real work of the turbine $W t(\mathrm{~kW})$. The real work of the turbine can be ascertained from other parameters: the generator output power $W g(\mathrm{~kW})$ and generator efficiency $\eta_{g}(\%)$.

$$
W t=W g / \eta_{g}
$$

The equation of exergy balance is:

$$
\begin{aligned}
\Sigma X 2 & =\Sigma X 4+W t+I_{\text {Turbin }} \\
\dot{m}_{2} e_{2} & =\dot{m}_{4} e_{4}+W t+I_{\text {Turbin }}
\end{aligned}
$$


The total amount of exergy of expanded steam $\Sigma X 2(\mathrm{~kW})$ is equivalent to the amount of exergy of exhaust steam $\Sigma X 4(\mathrm{~kW})$, the real work of turbine $W t(\mathrm{~kW})$, and irreversibility of turbine itself $I_{\text {Turbine }}(\mathrm{kW})$.

\subsection{Condenser}

The condenser is placed right below the turbine, connected together using an expansion joint. The exhaust steam from the turbine flows directly to the condenser, and is sprayed directly by cooling water from the cooling tower. This process results in the dropping of condenser pressure to vacuum pressure.

The level in the condenser is maintained at a specific level based on operational procedure, which is why there are two MCWPs pumping the condensate water into the cooling tower, so that the level can be balanced with the inlet water and exhaust steam, which are continually entering the condenser.

Table 3 Condenser unit 1-2-3

\begin{tabular}{lcc}
\hline \multicolumn{1}{c}{ Parameter } & Unit 1-2 & Unit 3 \\
\hline Manufacturer & \multicolumn{2}{c}{ Ansaldo Gie } \\
Type & Direct contact condenser \\
Internal volume & $504 \mathrm{~m}^{3}$ & $527 \mathrm{~m}^{3}$ \\
Number of spray nozzles & 315 & 576 \\
\hline
\end{tabular}

Some assumptions have been created for calculating and analyzing:

1. The process is thermodynamically adiabatic.

2. In this part of the calculation, NCG is counted in formulae, and is assumed to be $\mathrm{CO}_{2}$. Thermodynamic properties of NCG can be ascertained by reference to $\mathrm{CO}_{2}$ table properties.

The formula to calculate energy that works in the condenser is:

$$
\begin{gathered}
\Sigma E 4+\Sigma E 5+\Sigma E 6=\Sigma E 7+\Sigma E 8 \\
\dot{m}_{4} h_{4}+\dot{m}_{5} h_{5}+\dot{m}_{6} h_{6}=\dot{m}_{7} h_{7}+\dot{m}_{8} h_{8}
\end{gathered}
$$

The energy balance of this area is equivalent to the total energy input to the condenser. This consists of energy from the turbine exhaust steam $\Sigma \mathrm{E} 4(\mathrm{~kW})$, energy from the cooling water inlet $\Sigma \mathrm{E} 5(\mathrm{~kW})$, and condensate water from the inter-after condenser which is returning to condenser $\Sigma E 6(\mathrm{~kW})$. The output side from the condenser is the energy of condensate water which is pumped to the cooling tower $\Sigma E 7(\mathrm{~kW})$, and energy that is contained in NCG that is extracted by the ejector $\Sigma \mathrm{E} 7(\mathrm{~kW})$. The exergy balance in the condenser is shown in the equation:

$$
\begin{gathered}
\Sigma X 4+\Sigma X 5+\Sigma X 6=\Sigma X 7+\Sigma X 8+I_{\text {Condenser }} \\
\dot{m}_{4} e_{4}+\dot{m}_{5} e_{5}+\dot{m}_{6} e_{6}=\dot{m}_{7} e_{7}+\dot{m}_{8} e_{8}+I_{\text {Condenser }}
\end{gathered}
$$

As with the energy balance, the exergy balance in the output side of equation consists of the irreversibility of the condenser $\mathrm{I}_{\text {Condenser }}(\mathrm{kW})$.

\subsection{Inter-After Condenser}

The GRS consists of ejectors and the inter-after condenser. In order to maintain a vacuum in the condenser, NCG needs to be removed via motive steam in the ejectors. The motive steam and NCG both require cooling. The inter-after condenser conducts this cooling process by using cooling water from PCWP.

Several assumptions are made:

1. The motive steam is assumed to have No. NCG content. 
2. The ejector can extract the full content of NCG from the condenser.

The equation of energy balance is:

$$
\begin{aligned}
& \Sigma E 3+\Sigma E 8+\Sigma E 9=\Sigma E 6+\Sigma E 10 \\
& \dot{m}_{3} h_{3}+\dot{m}_{8} h_{8}+\dot{m}_{9} h_{9}=\dot{m}_{6} h_{6}+\dot{m}_{10} h_{10}
\end{aligned}
$$

The inlet side comprises motive steam $\Sigma E 3(\mathrm{~kW})$, NCG from the condenser $\Sigma E 8(\mathrm{~kW})$, and cooling water from the PCWP $\Sigma E 9(\mathrm{~kW})$. The outlet side comprises condensate from the interafter condenser $\Sigma E 6(\mathrm{~kW})$ and NCG to the fan stack of the CT $\Sigma E 10(\mathrm{~kW})$.

The exergy balance is:

$$
\begin{gathered}
\Sigma X 3+\Sigma X 8+\Sigma X 9=\Sigma X 6+\Sigma X 10+I_{I A} \\
\dot{m}_{3} e_{3}+\dot{m}_{8} e_{8}+\dot{m}_{9} e_{9}=\dot{m}_{6} e_{6}+\dot{m}_{10} e_{10}+I_{I A}
\end{gathered}
$$

$I_{I A}$ stands for irreversibility of Inter-after Condenser $(\mathrm{kW})$.

\subsection{Cooling Tower}

Using the induced draft cooling tower, the air stream flows horizontally through the water drops from the upper basin, so the lower basin is filled with a lower temperature of water, which is then used as cooling water in the condenser.

The equation for energy analysis can be expressed as:

$$
\begin{aligned}
\Sigma E 11+\Sigma E 12 & =\Sigma E 13+\Sigma E 14 \\
\dot{m} 11 h 11+\dot{m} 12 h 12 & =\dot{m} 13 h 13+\dot{m} 14 h 14
\end{aligned}
$$

The total inlet energy in the cooling tower is comprised of the energy from condensate water from MCWP $\Sigma E 11(\mathrm{~kW})$ and energy of the air stream inlet $\Sigma E 12(\mathrm{~kW})$. The total energy output is the energy of water flowing to the cold basin $\Sigma E 13(\mathrm{~kW})$ and the energy of the air stream flows to the atmosphere $\Sigma E 14$. $(\mathrm{kW})$. The exergy analysis can be stated as:

$$
\begin{gathered}
\Sigma X 11+\Sigma X 12+\text { Wpump }+ \text { Wfan } C T=\Sigma X 13+\Sigma X 14+I_{C T} \\
\dot{m}_{11} e_{11}+\dot{m}_{12} e_{12}+\text { Wpump }+ \text { Wfan } \\
C T=\dot{m}_{13} e_{13}+\dot{m}_{14} e_{14}+I_{C T}
\end{gathered}
$$

\section{RESULTS AND DISCUSSION}

\subsection{Reference Environment}

The altitude of certain places determines pressure, as does the temperature and humidity. These conditions are important factors in exergy analysis. The environment is assumed to be a very large, simple, and compressible system, modeled as a thermal reservoir with a uniform and constant temperature, $T_{0}$, and pressure $P_{0}$ (Kwambai, 2005).

Table 4. Reference environment

\begin{tabular}{lcc}
\hline \multicolumn{1}{c}{ Parameter } & Value & Unit \\
\hline Altitude & \pm 800 & meter above sea \\
& & level (MASL) \\
Pressure & \pm 912 & mbar \\
Temperature & $20-26$ & ${ }^{\circ} \mathrm{C}$ \\
Relative Humidity & $34-75$ & $\%$ \\
\hline
\end{tabular}




\subsection{Overall Power Plant Performance}

Results shows that Mount Salak Geothermal Power Plant Unit 1-2-3 had an overall first law efficiency of $16.75 \%$ and an overall second law efficiency of $59.27 \%$. These percentages were acquired via the ratio of total generator power output compared to the total of energy and exergy of steam entering the system. For more details in Table 5.

Table 5 Total of energy and exergy of unit 1-2-3

\begin{tabular}{lrrrrr}
\hline \multicolumn{1}{c}{ Parameter } & $\begin{array}{c}\text { Input } \\
(\mathrm{MWe})\end{array}$ & $\begin{array}{c}\text { Desired } \\
\text { Output } \\
(\mathrm{MWe})\end{array}$ & $\begin{array}{c}\text { Irreversibility } \\
(\mathrm{MWe})\end{array}$ & $\begin{array}{c}\text { Waste } \\
\text { Exergy } \\
(\mathrm{MWe})\end{array}$ & Eff(\%) \\
\hline Exergy in Demister & 302.415 & 296.317 & 6.097 & 0 & 97.984 \\
Exergy in Turbine & 281.502 & 182.999 & 20.382 & 75.31 & 65 \\
Exergy in Condenser & 84.512 & 51.332 & 32.849 & 0 & 60.74 \\
Exergy in Inter-After Condenser & 15.152 & 4.76 & 5.703 & 4.873 & 31.391 \\
Total Energy of Steam & 1069.901 & 179.25 & & & 16.754 \\
Total Exergy of Steam & 302.415 & 179.25 & 123.165 & 59.273 \\
\hline
\end{tabular}

Steam flow to the demister comprised the total energy enter the system. The total energy is 1069.9 MWe, and total exergy is 302.415. MWe of steam flow to demister Unit 1-2-3. These details are clarified in the Sankey diagram below.

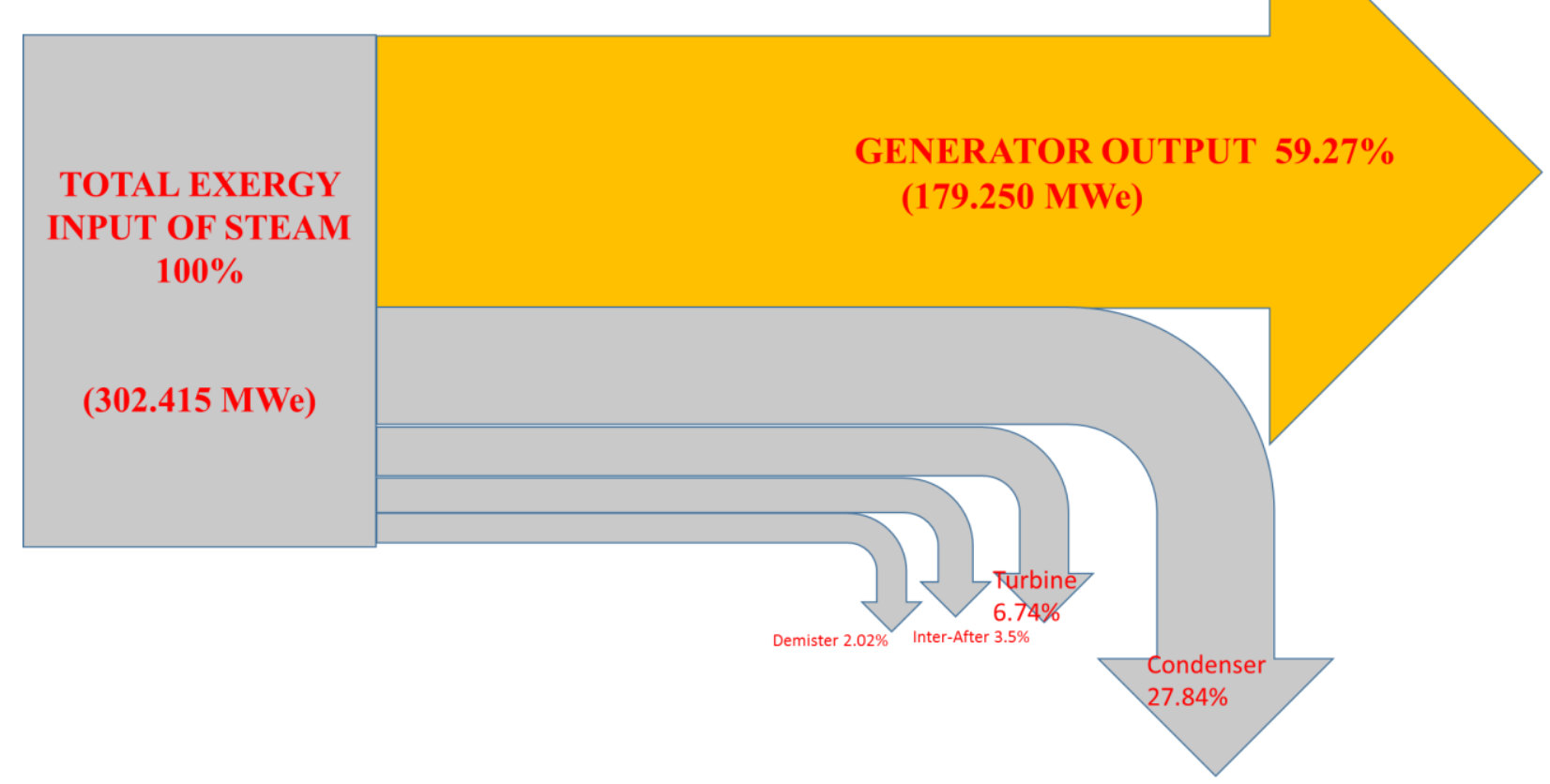

Figure 2 Overall process described in Sankey Diagram

The desired output of overall power generation is the total power of generator output: 179.25 MWe. To achieve a higher power plant efficiency, a higher generator output with less steam consumption is required.

Beside the desired output, other parameters - irreversibility and waste exergy - are important. Irreversibility means exergy that is destructed within the process, while waste exergy is exergy that is wasted. Waste exergy is usually in the form of exhaust steam or condensate water that 
cannot be converted into work. The total irreversibility and waste exergy is $123.165 \mathrm{MWe}$, which can also be described as the inefficiency of total power generation.

As stated in the introduction, this research aims to find possible ways to improve the performance of power plants by identifying the losses that happen in every process. There are at least two criteria in the purpose of this research.

The first criteria is the maintenance of reliable power generation through making sure all units must be able to produce at the maximum capacity of the generator i.e. producing $60 \mathrm{MWe}$ for each unit. The second criteria is the increase of efficiency for maintained sustainability of the power plant. Considering recent conditions, the main concern here is steam flow requirements. Owing to its long operation to produce same amount electricity, more amount of steam is needed. This is connected to equipment degrading over time. The largest irreversibility was identified in the condensers, at $27.84 \%$ of the total process. The results show that irreversibility occurred due to the fact that there are large temperature difference (Martin et al., 2016). In this case, between working fluids, exhaust steam and cooling water.

\subsection{Discussion on Improvement}

For the purpose of further discussion, a root cause analysis diagram is given below to locate possibilities for improvement based on the recent condition of power plants. As a comparison, data is shown from performance tests after uprating Unit 1-2-3 to 60 MWe in Table. 6.

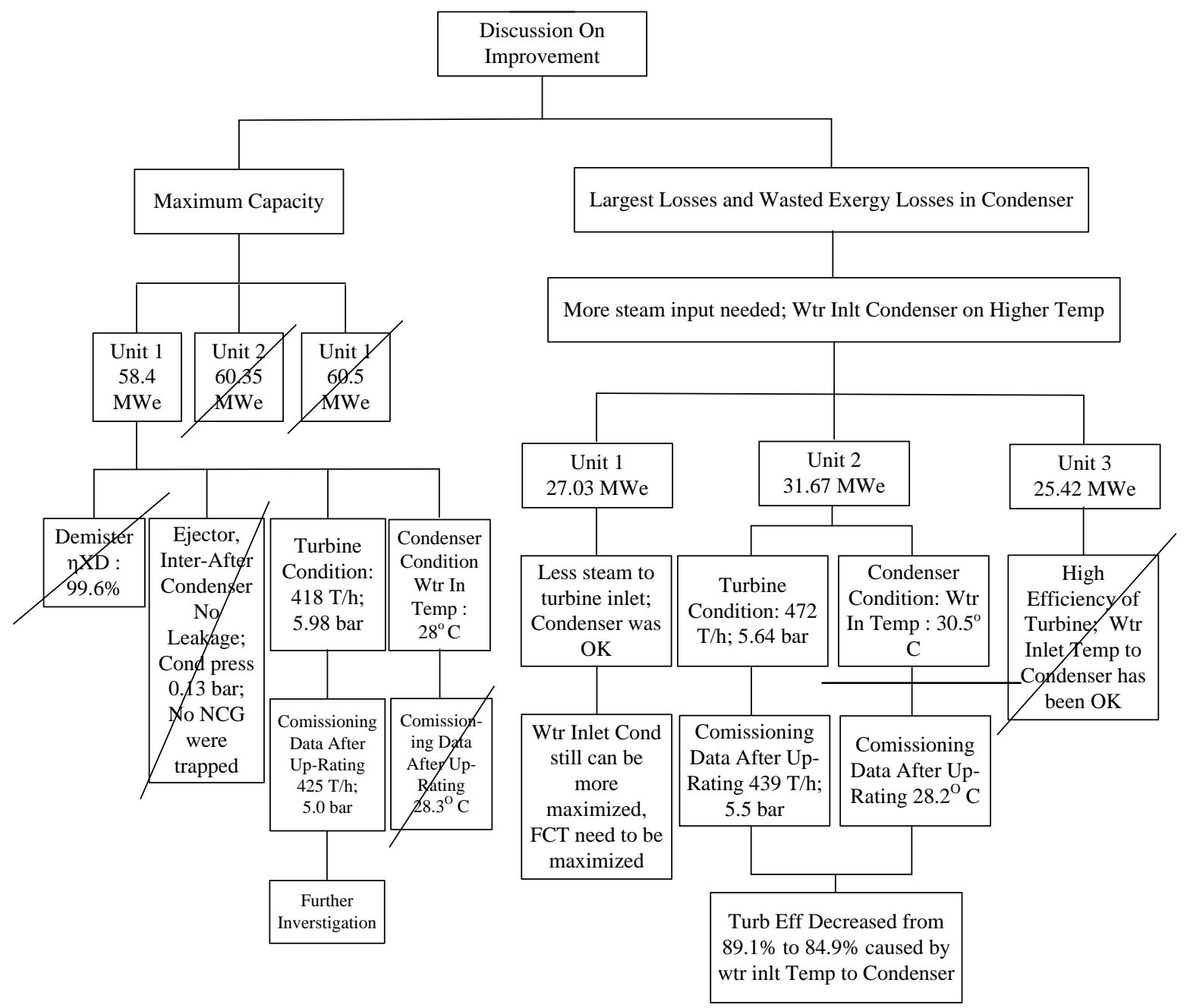

Figure 3 RCA diagram for discussion on improvement 
Table 6. Data comparison unit 1-2-3

\begin{tabular}{|c|c|c|c|c|c|c|c|}
\hline \multirow[b]{2}{*}{ Parameter } & \multirow[b]{2}{*}{ Unit } & \multicolumn{2}{|c|}{ Unit 1} & \multicolumn{2}{|c|}{ Unit 2} & \multicolumn{2}{|c|}{ Unit 3} \\
\hline & & $\begin{array}{c}\text { After } \\
\text { Uprating } \\
\text { April } \\
2005\end{array}$ & $\begin{array}{l}\text { Recent } \\
\text { Data }\end{array}$ & $\begin{array}{c}\text { After } \\
\text { Uprating } \\
\text { April } \\
2005\end{array}$ & $\begin{array}{c}\text { Recent } \\
\text { Data }\end{array}$ & $\begin{array}{c}\text { After } \\
\text { Uprating } \\
\text { Sept } \\
2004\end{array}$ & $\begin{array}{c}\text { Recent } \\
\text { Data }\end{array}$ \\
\hline $\begin{array}{l}\text { Generator } \\
\text { Output }\end{array}$ & Mwe & 60.2 & 58.4 & 60.4 & 60.34 & 60.2 & 60.5 \\
\hline $\begin{array}{l}\text { Steam } \\
\text { Flow }\end{array}$ & $\mathrm{T} / \mathrm{h}$ & 425 & 418 & 439 & 472 & 446 & 442 \\
\hline $\begin{array}{l}\text { Turbine } \\
\text { Inlet Temp }\end{array}$ & ${ }^{\circ} \mathrm{C}$ & 164.5 & 164.9 & 166.1 & 165 & 162.2 & 163 \\
\hline $\begin{array}{l}\text { Turbine } \\
\text { Inlet Press }\end{array}$ & bar & 5 & 5.98 & 5.5 & 5.64 & 4.5 & 5.24 \\
\hline $\begin{array}{l}\text { Turbine } \\
\text { Exhaust } \\
\text { Temp }\end{array}$ & ${ }^{\circ} \mathrm{C}$ & 49.8 & 56.2 & 51.6 & 57.4 & 49.3 & 54.4 \\
\hline $\begin{array}{l}\text { Cond } \\
\text { Press }\end{array}$ & bar & 0.12 & 0.13 & 0.13 & 0.16 & 0.1 & 0.15 \\
\hline $\begin{array}{l}\text { Inlet Cond. } \\
\text { Temp }\end{array}$ & ${ }^{\circ} \mathrm{C}$ & 28.2 & 28 & 28.2 & 30.2 & 29.3 & 27.8 \\
\hline $\begin{array}{l}\text { Isentropic } \\
\text { Turb Eff }\end{array}$ & $\%$ & 87.1 & 90.72 & 89.1 & 84.91 & 87.87 & 89.93 \\
\hline $\begin{array}{l}\text { FCT that } \\
\text { Operating }\end{array}$ & Total & 5 in $\mathrm{HS}$ & $\begin{array}{l}3 \text { in HS; } \\
2 \text { in LS }\end{array}$ & 5 in $\mathrm{HS}$ & $\begin{array}{c}3 \text { in HS; } \\
1 \text { in LS }\end{array}$ & 4 in HS & 4 in $\mathrm{HS}$ \\
\hline
\end{tabular}

HS = High Speed; LS = Low Speed

Recent data shows that Unit 1 is not able to generate maximum capacity, unlike Unit 2-3. The generator output is respectively an average of $58.4 \mathrm{MWe}, 60.35 \mathrm{MWe}$, and $60.5 \mathrm{MWe}$. The difference is also seen in steam consumption, with respective measures of $417 \mathrm{t} / \mathrm{h}, 472 \mathrm{t} / \mathrm{h}$ and $442 \mathrm{t} / \mathrm{h}$. This condition started after January 2016.

Demister efficiency in Unit 1 shows great performance at 99.6\%. Another main equipment, the inter-after condenser, shows no leakage, illustrating that NCG is well extracted by the ejector and the condenser pressure is in a normal condition at 0.13 bar abs. The temperature of the cooling water inlet condenser can impact the vacuum condenser too, but it shows improvement compared to data after uprating in 2005. Lower steam consumption may be affected when turbine chest pressure is higher. It increases from 5 bar abs to 5.98 bar abs, which in turn decreases steam flow to around $7 \mathrm{t} / \mathrm{h}$. Turbine condition requires further investigation, as this may be connected to the constriction of turbine in Unit 1.

Another concern is the efficiency of the power plant, to achieve nominal power generation capacity with less steam supply (Adiprana et al., 2015). This requires turbine efficiency. Turbine efficiency is highly connected to the cooling water temperature entering condensers. Moreover, it is affected by the work of FCT. In normal operations, Unit 1-2 needs 5 FCT to operate in high speed, whereas in Unit 3 only 4 FCT in High Speed as well. FCT forces an air stream to the CT building to cool the hot condensate water. Thus if it is operating normally, more air streams will be in contact with water and a lower temperature in the cold basin can be achieved. 
In the latest condition of Unit 1, results shows that turbine efficiency is increasing when compared with data collated in 2005 . However, it can be yet further maximized by operating FCT in maximal. In their latest conditions, two of them cannot be operated at maximum speed.

In Unit 2, turbine performance is shown as decreasing $4.2 \%$, which means that generation of the same amount of electricity requires more than $41 \mathrm{t} / \mathrm{h}$. This is caused by the temperature of cooling water to the condenser increasing from 28.2 to $30.5^{\circ} \mathrm{C}$. Generation can be maximized by improving the performance of the FCT. In Unit 2, there is one FCT that cannot be operated, and another one that is only able to be operated at low speed. As a result, performance is very much impacted by the ability to produce lower temperatures of cooling water.

\section{CONCLUSION}

The total energy and exergy of steam entering power plant systems are $1069.90 \mathrm{MWe}$ and 302.42 MWe. Mount Salak Geothermal Power Plant Unit 1-2-3 has an overall first law efficiency of $16.75 \%$ and an overall second law efficiency of $59.27 \%$. Further investigation in Unit 1 needs to be done as soon as possible to achieve production at maximum capacity. The largest losses of exergy were in the condensers, which came to $27.84 \%$ of total exergy. This is because of the higher demand for steam to generate the turbine and produce maximum work. This condition is affected by the quality of water used to cool the exhaust steam in the condenser, which is in turn affected by the condition of the cooling tower, where FCT cannot be operated maximally. Higher temperatures of cooling water decreases turbine efficiency, and means that, in order to produce the same amount of output energy as maximum capacity, the turbine needs more incoming energy in the form of more steam. In conclusion, further maintenance that focuses on FCT is imperative, so that losses in exergy in the condenser are reduced, and power plant efficiency is overall increased by using less steam to produce the same amount of electricity.

\section{ACKNOWLEDGEMENT}

The authors would like to acknowledge Operation Division of PT. Indonesia Power Mount Salak Geothermal Power Plant who have been very helpful during the research process, particularly in the provision of data used for calculations.

\section{REFERENCES}

Adiprana, R., Purnomo, D.S., Lubis, I.E., 2015. Kamojang Geothermal Power Plant Unit 1-2-3 Evaluation and Optimization based on Exergy Analysis. In: Proceedings World Geothermal Congress 2015, Melbourne, April 19-25, Australia

Aljundi, I.H., 2009. Energy and Exergy Analysis of a Steam Power Plant in Jordan. Applied Thermal Engineering, Volume 29(2-3), pp. 324-328

Ameri, M., Amanpour, S., Amanpour, S., 2011. Energy and Exergy Analysis and Optimization of a Double Flash Power Plant for Meshkin Shahr Region. In: World Renewable Energy Congress 2011. Linkoping, May 8-13, Sweden

Cengel, A.Y., Boles, M.A., 2006. Thermodynamics Engineering Approach, Fifth Edition, McGraw Hill Companies, New York, USA

Dagdas, A., 2007. Performance Analysis and Optimization of Double-flash Geothermal Power Plants. Journal of Energy Resources Technology, Volume 129(2), pp. 125-133

Dincer, I., Rosen, M.A., 2013. Exergy, Energy, Environment and Sustainable Development, Exergy Handbook, ( $2^{\text {nd }}$ edition $)$, Elsevier, Oxford, UK

DiPippo, R., 2007. Geothermal Power Plants. Second Edition: Principle, Applications, Case Studies and Environmental Impact, Butterworth-Heinemann, Massachusetts, USA 
Gong, M., Wall, G., 1997. On Exergetics, Economics and Optimization of Technical Processes to Meet Environmental Conditions. In: Proceedings, Thermodynamic Analysis and Improvement of Energy Systems, Beijing, June 10-13, China

Jalilinasrabady, S., Itoi, R., Valdimarssin, P., Saevarsdottir, G., Fujii, H., 2012. Flash Cycle Optimization of Sabalan Geothermal Power Plant Employing Exergy Concept. Geothermies, Volume 43, pp 75-82

Khorami M., Mehrasa B., Khorami M., 2013. Energy and Exergy Analysis of a Geothermal Power Station with Two-phase Closed Thermosyphon System in an Organic Rankine Cycle. International Journal of Advances in Engineering \& Technology, Volume 5(2), pp. $52-62$

Kwambai, C.B., 2005. Exergy Analysis of Olkaria I Power Plant Kenya. Geothermal Training Program, The United Nations University Reykjavik, Iceland

Martin, A., Miswandi, Prayitno, A., Kurniawan, I., Romy, 2016. Exergy Analysis of Gas Turbine Power Plant $20 \mathrm{MW}$ in Pekanbaru-Indonesia. International Journal of Technology, Volume 7(5), pp. 921-927

Moran, M.J., Shapiro, H.N., 2006. Fundamentals of Engineering Thermodynamics, $3^{\text {rd }}$ ed., John Wiley \& Sons, Hoboken, New Jersey, USA

Pambudi, N.A, Itoi, R., Jalilinasrabady, S., Khasani, 2013. Performance Evaluation of Double Flash Geothermal Power Plant at Dieng using Second Law of Thermodynamics. In: Proceedings, Thirty-Eighth Workshop on Geothermal Reservoir Engineering Stanford University 2013, California, February 11-13, USA

Quijano J., 2000. Exergy Analysis for the Ahuachapan and Berlin Geothermal Fields, El Savador. In: Proceedings World Geothermal Congress 2000. Kyushu-Tohoku, May 28 June 10, Japan

Rosen, M.A., 2002. Does Industry Embrace Exergy?. International Journal of Exergy, Volume 2(4), pp. 221-223

Self S.J, Reddy B.V., Rosen M.A., 2015. Energy and Exergy Analyses of Geothermal Power Plants with and without Re-injection. Research Journal of Environmental Sciences, Volume 9 (2), pp. 74-87 